\title{
Textural and geochemical evidence for magnetite production upon antigorite breakdown during subduction
}

\author{
JOANA F. VIEIRA DUARTE, FRANCESCA PICCOLI, DR. \\ THOMAS PETTKE AND JÖRG HERMANN \\ University of Bern \\ Presenting Author: Joana.vieira@geo.unibe.ch
}

The stability of magnetite along with other opaque minerals in ultramafic rocks during subduction plays a major role in controlling redox states of the fluids liberated upon dehydration reactions, as well as of the residual rocks. Despite their importance for the evaluation of the redox conditions, the systematics and geochemistry of opaque minerals have remained poorly constrained in subducted ultramafic rocks.

We present a detailed petrological and geochemical study of oxide - silicate mineral assemblages in hydrous ultramafic rocks from Cerro del Almirez (Spain). Our results indicate that prograde to peak magnetite, ilmenite-hematite solid solution minerals, and sulfides coexist in both antigorite-serpentinite and chlorite-harzburgite at ca. $670{ }^{\circ} \mathrm{C} / 1.6 \mathrm{GPa}$, displaying successive crystallization stages. Each stage is characterized by specific mineral assemblages and compositions. In antigoriteserpentinite, magnetite inherited from seafloor hydration and magnetite (re)crystallized during subduction has moderate $\mathrm{Cr}$ $\left(\mathrm{Cr}_{2} \mathrm{O}_{3}<10\right.$ wt.\%) and low $\mathrm{Al}$ and $\mathrm{V}$ concentrations. In chloriteharzburgite, polygonal magnetite is in textural equilibrium with olivine, orthopyroxene, chlorite, pentlandite, and ilmenitehematite solid solution. It contains up to 19 wt. $\% \mathrm{Cr}_{2} \mathrm{O}_{3}$, along with higher $\mathrm{Al}$, and $\mathrm{V}$, derived from antigorite breakdown and lower $\mathrm{Mn}$ concentrations due to coexistence with olivine and orthopyroxene. $\mathrm{Cr}-\mathrm{V}-\mathrm{Al}-\mathrm{Fe}^{3+}$ mass balance calculations indicate that serpentinites and chlorite-harzburgites had different initial bulk compositions and thus cannot be directly compared. Our mass balance analysis also reveals that in order to account for the mass conservation of fluid-immobile elements such as Cr-V-Al$\mathrm{Fe}^{3+}$, new magnetite formation is required across the antigoritebreakdown reaction.

Stability and formation of magnetite in equilibrium with peak silicate and sulfide assemblage, together with the observation of Fe-Ti solid solution minerals, indicates that redox conditions of the released fluid are 1-2 log units above the QFM buffer. We conclude that antigorite-dehydration reaction fluids carry only a moderate redox budget and therefore cannot account for the relatively oxidized nature of arc magmas. 